\title{
PERAN LINGKUNGAN DAN INDIVIDU TERHADAP MASALAH DIARE DI PULAU JAWA DAN BALI
}

\section{The Role of the Environment and Individual towards Diarrhea Problems in Java and Bali}

\author{
Ika Dharmayanti ${ }^{1}$, Dwi Hapsari Tjandrarini ${ }^{1}$ \\ ${ }^{1}$ Badan Penelitian dan Pengembangan Kesehatan, Jl. Percetakan Negara No.29 Jakarta Pusat \\ Email: ika.echadh@gmail.com
}

Diterima: 11 Mei 2020; Direvisi: 17 Juli 2020; Disetujui: 23 September 2020

\begin{abstract}
Diarrhea is a major health problem in Indonesia with high morbidity and mortality rates. Unhealthy environment and unhygienic behavior are closely related to diarrhea disease. This study aims to identify the association between environmental conditions and behavior with the occurrence of diarrhea in Jawa and Bali. Data source used was the integration data of March's Susenas and Riskesdas 2018. A logistic regression analysis was chosen to elicit the relationship between sanitation and drinking water facilities, open defecation practice, and other factors with the prevalence of diarrhea. The results showed that open defecation $(O R=1.2 ; 95 \%$ CI: 1.12 to 1.29; $P<0.001$, and improper of household sanitation and drinking water $(O R=1.11 ; 95 \% C I: 1.04$ to $1.2 ; P=0.003)$ had significant association with diarrhea. Other factors are age $0-5$ years $(O R=1.56 ; 95 \% C I: 1.46$ to $1.66 ; P<0,001)$ and low education $(O R=1.33$; 95\% CI: 1.21 to 1.47; $P<0,001)$. This study shows the hygienic behavior is the essential factors to reduce the incidence of diarrhea. Therefore, it is recommended to to prioritize aspects of behavior and environmental health, namely changing people's behavior to defecate in a latrine, and provide proper sanitation and sufficient drinking water.
\end{abstract}

Keywords: Diarrhea; sanitation; drinking water; open defecation

\begin{abstract}
ABSTRAK
Penyakit diare merupakan masalah kesehatan utama di Indonesia dengan angka kesakitan dan kematian yang masih tinggi. Lingkungan yang tidak sehat dan perilaku tidak higienis sangat erat kaitannya dengan penyakit diare. Penelitian ini bertujuan untuk menganalisis hubungan antara kondisi lingkungan dan perilaku dengan penyakit diare di pulau Jawa dan Bali. Sumber data yang digunakan adalah data integrasi Susenas Maret dan Riskesdas 2018. Analisis dilakukan dengan menggunakan regresi logistik untuk melihat hubungan antara ketersediaan sanitasi dan air minum, perilaku buang air besar serta faktor lainnya terhadap kejadian diare. Hasil menunjukkan bahwa faktor perilaku buang air besar sembarangan $(\mathrm{OR}=1,2 ; 95 \% \mathrm{CI}$ : $1,12$ - 1,29; $\mathrm{P}<0,001)$ serta akses sanitasi dan air minum rumah tangga tidak layak/tidak tersedia $(\mathrm{OR}=$ $1,11 ; 95 \%$ CI: $1,04-1,2 ; \mathrm{P}=0,003)$ memiliki hubungan dengan kejadian diare. Faktor lainnya yaitu: usia 0-5 tahun $(\mathrm{OR}=1,56 ; 95 \% \mathrm{CI}: 1,46-1,66 ; \mathrm{P}<0,001)$ dan pendidikan rendah $(\mathrm{OR}=1,33 ; 95 \% \mathrm{CI}: 1,21-$ 1,47; P <0,001). Penelitian ini menunjukkan bahwa perilaku higienis sangat penting untuk menurunkan kejadian diare. Oleh karena itu direkomendasikan untuk mengutamakan aspek perilaku dan kesehatan lingkungan, yaitu merubah perilaku masyarakat untuk BAB di jamban, serta menyediakan sanitasi dan air minum yang layak.
\end{abstract}

Kata kunci: Diare, sanitasi, sarana air minum, buang air besar sembarangan

\section{PENDAHULUAN}

Penyakit diare masih menjadi masalah kesehatan di berbagai negara, terutama di negara berkembang seperti di Indonesia. Masih tingginya angka kesakitan dan kematian akibat diare menjadikan penyakit ini masih membutuhkan perhatian besar dari pemerintah. Organisasai Kesehatan Dunia (WHO) dan Dana Anak-Anak Perserikatan Bangsa Bangsa (UNICEF) memperkirakan dua milyar kasus diare di dunia setiap tahun dan 1,9 juta anak-anak 
dibawah umur 5 tahun meninggal yang sebagian besar terjadi di negara berkembang (World Gastroenterology Organisation, 2012).

Data dan informasi dari profil kesehatan Indonesia tahun 2019 menunjukkan bahwa angka kesakitan diare di Indonesia masih cukup tinggi. Pada tahun 2019 angka kesakitan diare untuk semua umur sebesar 270/1000 penduduk sedangkan pada balita sebesar 843/1000 penduduk (Kesehatan Kemenkes RI, 2020). Hasil Riset Kesehatan Dasar (Riskesdas) menyatakan bahwa penyakit diare, menurut diagnosis dokter dan gejala yang pernah dialami, mengalami peningkatan dari $7 \%$ pada tahun 2013 menjadi 8\% pada tahun 2018 (Kemenkes RI, 2018).

Data laporan Rumah Sakit di Indonesia tahun 2008 menyebutkan penyakit diare dan gastroenteritis merupakan penyakit urutan pertama dari sepuluh penyakit dari pasien rawat inap di rumah sakit (Kemenkes RI, 2011). Selain itu, kejadian luar biasa (KLB) diare juga masih cukup sering terjadi Indonesia dengan angka kematian (case fatality rate/CFR) yang masih tinggi. Berdasarkan profil kesehatan Indonesia 2019 terlihat bahwa frekuensi KLB penyakit diare mengalami fluktuasi (naik-turun), akan tetapi angka kematian terus meningkat. Kasus KLB pada tahun 2015 mencapai 1.213 orang yang terjadi di 13 provinsi dengan angka kematian 2,47\%. Selanjutnya pada tahun 2016 terjadi KLB di 3 provinsi dengan jumlah kasus 198 orang dan angka kematian CFR 3,03\%. Pada tahun 2018 terjadi KLB diare sebanyak 10 kasus yang tersebar di 8 provinsi di 8 kabupaten/kota dengan 756 orang penderita dan angka kematian sebesar 4,76\% (Kemenkes RI, 2019).

Provinsi Jawa dan Bali tercatat mengalami KLB diare paling sering. Pada tahun 2018 terjadi KLB dengan jumlah kasus sebanyak 216 orang. Selain itu, prevalensi diare per-provinsi di pulau Jawa dan Bali juga cukup tinggi. Menurut laporan Riskesdas 2018 prevalensi diare di beberapa Provinsi di Jawa dan Bali lebih tinggi dibandingkan dengan angka nasional; yaitu berkisar antara 7,2 - 9,2 \% (Tabel 1).

Tabel 1. Prevalensi diare tahun 2007 - 2018 di Provinsi Jawa-Bali

\begin{tabular}{lcccccc}
\hline \multirow{2}{*}{ Provinsi } & \multicolumn{7}{c}{ Prevalensi diare (\%) } \\
\cline { 2 - 7 } & \multicolumn{2}{c}{2007} & \multicolumn{2}{c}{2013} & \multicolumn{2}{c}{2018} \\
\cline { 2 - 7 } & $\mathrm{D}^{*}$ & $\mathrm{D} / \mathrm{G}^{* *}$ & $\mathrm{D}$ & $\mathrm{D} / \mathrm{G}$ & $\mathrm{D}$ & $\mathrm{D} / \mathrm{G}$ \\
\hline DKI Jakarta & 5,8 & 8 & 5 & 8,6 & 5,7 & 7,2 \\
Jawa Barat & 5,8 & 10,2 & 4,9 & 7,5 & 7,4 & 8,6 \\
Jawa Tengah & 4,8 & 9,2 & 4,7 & 6,7 & 7,2 & 8,4 \\
Di Yogyakarta & 2,6 & 4,2 & 3,8 & 6,6 & 6,1 & 8,5 \\
Jawa Timur & 4,9 & 7,8 & 4,7 & 7,4 & 6,5 & 7,6 \\
Banten & 5 & 10,6 & 4,3 & 6,4 & 7,6 & 9,2 \\
Bali & 5,2 & 7,3 & 3,6 & 5,5 & 6,6 & 8,3 \\
\hline Indonesia & 5,1 & 9 & 4,5 & 7 & 6,8 & 8 \\
\hline
\end{tabular}

Catatan: *Diagnosis; **Diagnosis dan Gejala

Sumber: Laporan Riset Kesehatan Dasar, Balitbangkes, Kemenkes (akses Maret 2020)

Salah satu faktor penting yang terkait dengan penyebaran penyakit diare yaitu faktor lingkungan dan perilaku. Faktor lingkungan meliputi ketersediaan sarana air minum, penggunaan jamban dan pembuangan limbah rumah tangga. Sementara faktor perilaku, meliputi pentingnya kebiasaan buang air besar di jamban, mencuci tangan dengan menggunakan sabun dan air mengalir, serta kebiasaan memasak air mempunyai dampak yang besar dalam menurunkan risiko penyakit diare (Soekidjo, 2003; Kemenkes RI, 2011; Statistik et al., 2016).

Penularan penyakit diare pada umumnya melalui cara fekal-oral atau disebut juga fecal - oral transmission yaitu melalui fluids, fields, flies dan Fingers (UNICEF/WHO, 2009; WHO, 2018). Cara penularan penyakit ini dapat melalui 
makanan dan/atau minuman yang terkontaminasi, adanya kontak langsung dengan tangan yang terkontaminasi, atau makanan yang wadah atau tempat makan dan/atau minum yang dicuci dengan air yang tercemar (Kemenkes RI, 2011). Sumber air yang terkontaminasi bakteri Escherichia Coli (E.coli) umumnya disebabkan oleh pencemaran tinja manusia akibat dari sanitasi yang buruk. Data hasil survey kualitas air di Daerah Istimewa Yogyakarta (DIY) menyebutkan bahwa sumber air minum di DIY sudah tercemar bakteri E.coli. Sebanyak 90,4\% sumber air dari tanah dan $77,4 \%$ sumber air perpipaan telah terkontaminasi E.coli. Bahkan, air siap minum tidak luput dari kontaminasi E.Coli sebesar 67,1\% (Badan Pusat Statistik et al., 2015). Hasil survey ini menunjukkan bahwa sanitasi yang buruk berakibat pada penurunan kualitas air yang dikonsumsi masyarakat. Pengaruh dari buruknya sanitasi akan menyebabkan $4 \%$ kematian dan 5\% masalah kesehatan, khususnya penyakit diare (WHO, 2007).

Risiko penyakit diare di Provinsi Jawa Bali, umumnya terkait dengan kesehatan lingkungan serta perilaku yang tidak sehat. Data profil kesehatan Provinsi Jawa Tengah 2017 menyebutkan bahwa KLB diare menduduki urutan ke-3 berdasarkan jumlah kejadian penyakit di Jawa Tengah. Permasalahan diare di Jawa Tengah terutama berhubungan dengan sarana air minum yang tidak layak dan cara penyajian makanan yang tidak higienis (Dinas Kesehatan Provinsi Jawa Tengah, 2018). Di Provinsi Jawa Barat, kasus diare umumnya dikaitkan dengan makanan yang kotor/terkontaminasi, ketersediaan air minum dan ketersediaan jamban yang belum memadai. Selain itu, rata-rata kasus KLB diare di Jawa Barat lebih dari 10.000 kasus (Dinas Kesehatan Provinsi Jawa Barat, 2017). Untuk wilayah DKI Jakarta, tingginya kasus diare disebabkan oleh kebersihan lingkungan yang buruk dan angka kemiskinan yang tinggi (Dinkes Provinsi DKI Jakarta, 2016). Sedangkan data profil Provinsi Bali menyebutkan bahwa diare merupakan penyakit terbanyak ke-2 dari 10 besar penyakit pada pasien rawat inap di RSUD Provinsi Bali tahun 2017, dengan risiko terbanyak akibat akses sanitasi yang tidak layak (Dinas Kesehatan Provinsi Bali, 2018).
Berdasarkan permasalahan tersebut, maka perlu adanya pembuktian bahwa faktor lingkungan yaitu sanitasi dan sarana air minum serta perilaku higienis yang meliputi perilaku buang air besar dapat berpengaruh terhadap kejadian diare di Provinsi Jawa dan Bali. Tulisan ini bertujuan untuk menilai hubungan antara akses sarana air minum dan sanitasi serta perilaku buang air besar dengan kejadian diare di Provinsi Jawa Bali.

\section{BAHAN DAN CARA}

Sumber data yang digunakan adalah data integrasi Riskesdas 2018 milik Badan Penelitian dan Pengembangan Kesehatan dan data Susenas Maret 2018 milik Badan Pusat Statistik. Rancangan penelitian menggunakan potong lintang (cross sectional) sehingga variabel terikat dan variabel bebas dipotret dalam waktu yang sama. Sampel yang digunakan pada analisis ini adalah semua individu di Pulau Jawa dan Bali dengan kriteria inklusi adalah individu tinggal di rumah tangga yang mengakses jamban. Jumlah sampel sebesar 278.132 individu.

Variabel terikat dalam analisis ini adalah kejadian diare, yaitu individu yang pernah didiagnosis menderita diare oleh tenaga kesehatan (nakes) dalam 1 bulan terakhir sebelum wawancara (0 jika pernah mengalami diare dan 1 jika tidak menderita diare), sedangkan variabel bebas adalah

a) Sanitasi dasar didefinisikan sebagai sarana untuk buang air besar yang hanya digunakan oleh rumah tangga sendiri, jenis kloset leher angsa dan tempat pembuangan akhir tinja dengan tangki septik serta 5 tahun terakhir pernah dilakukan penyedotan; jamban terbatas yaitu sarana buang air besar yang digunakan bersama rumah tangga lainnya, jenis kloset leher angsa dan tempat pembuangan akhir tinja dengan tangki septik/IPAL; jamban tidak layak yaitu sarana buang air besar plengsengan dengan atau tanpa tutup, dan cemplung cubluk; dan yang terakhir tidak menggunakan jamban yaitu memiliki akses terhadap jamban tetapi tidak menggunakannya,

b) Sarana air rumah tangga dasar adalah air yang berasal dari air kemasan bermerk, 
air isi ulang, leding, sumur bor/pompa, sumur terlindung, mata air terlindung, dan air hujan dengan waktu yang dibutuhkan untuk mengambil air pulang pergi dari rumah tidak lebih dari 30 menit; sarana air rumah tangga terbatas adalah air yang berasal dari air kemasan bermerk, air isi ulang, leding, sumur bor/pompa, sumur terlindung, mata air terlindung, dan air hujan dengan waktu yang dibutuhkan untuk mengambil air pulang pergi dari rumah lebih dari 30 menit; sarana air rumah tangga tidak layak adalah sumur gali tidak terlindung, mata air tidak terlindung; dan tidak ada sarana air rumah tangga adalah rumah tangga yang menggunakan air permukaan (sungai, danau, waduk, kolam dan irigasi),

c) Perilaku buang air besar (BAB) yaitu perilaku masyarakat dalam buang air besar (BAB di jamban dan tidak di jamban),

d) Akses sanitasi dan air minum rumah tangga yaitu variabel komposit dari akses sanitasi dan sarana air minum rumah yang dikelompokkan menjadi 3 kategori: (0) sanitasi dan sarana air minum tidak layak dan tidak tersedia/tidak digunakan; (1) sanitasi dan sarana air minum terbatas; (2) sanitasi dan sarana air minum dasar, e) Pendidikan yaitu tidak sekolah hingga tidak tamat SD; SD sampai dengan SMP; SMA sampai dengan perguruan tinggi,

f) Umur individu yaitu 0-5 tahun dan 6 tahun keatas.

Uji statistik menggunakan uji regresi logistik dengan prosedur analisis data survey yaitu menggunakan nilai penimbang, strata, dan primary sampling unit sehingga penyamaan peluang terpilih secara random sudah diperhitungkan saat proses analisis.

\section{HASIL}

Berdasarkan hasil analisis terlihat permasalahan diare di regional Jawa-Bali sekitar 7\%. Tabel 2 memperlihatkan gambaran masalah diare menurut karakteristik demografi. Proporsi diare terlihat tinggi pada anak berumur lima tahun ke bawah. Kelompok tersebut merupakan kelompok rentan. Sejalan dengan hal tersebut, masalah diare terlihat tinggi pada kelompok belum sekolah dan belum bekerja. Selain itu proporsi diare juga tinggi pada kelompok status ekonomi rendah. Menurut lokasi tempat tinggal, proporsi diare tidak jauh berbeda antara di perdesaan maupun di perkotaan. 
Tabel 2. Proporsi diare menurut karakteristik demografi, di Jawa-Bali Tahun 2018

\begin{tabular}{lccr}
\hline \multicolumn{1}{c}{ Karakteristik } & \multicolumn{2}{c}{ diare $(\%)$} & \multirow{2}{*}{ No278.132 } \\
\cline { 2 - 3 } Umur & \multicolumn{1}{c}{ Ya } & & \\
$0-5$ & 10,6 & 89,4 & 27.391 \\
6 tahun keatas & 6,5 & 93,5 & 250.741 \\
Pendidikan & & & \\
Tidak/belum sekolah & 7,5 & 92,5 & 158.611 \\
SD-SMP & 6,3 & 93,7 & 103.062 \\
SMA-PT & 5,1 & 94,9 & 16.459 \\
Pekerjaan & & & \\
Tidak/belum bekerja & 8,8 & 91,2 & 45.944 \\
Mengurus rumah tangga & 6,9 & 93,1 & 50.605 \\
Sekolah & 6,9 & 91,2 & 39.692 \\
Bekerja & 6,3 & 93,7 & 130.224 \\
Lainnya & 6,7 & 93,3 & 11.668 \\
Kepemilikan rumah & & & \\
Kontrak/sewa & 6,9 & 93,1 & 24.788 \\
Bebas sewa/dinas/lainya & 7,2 & 92,8 & 25.985 \\
Milik sendiri & 6,9 & 93,1 & 227.359 \\
Status ekonomi & & & \\
Rendah & 7,3 & 92,7 & 91.344 \\
Menengah-tinggi & 6,7 & 93,3 & 186.788 \\
Lokasi rumah tangga & & & \\
Perdesaan & 7,0 & 93,0 & 91.385 \\
Perkotaan & 6,9 & 93,1 & 186.747 \\
Total & $\mathbf{6 . 9}$ & $\mathbf{9 3 . 1}$ & $\mathbf{2 7 8 . 1 3 2}$ \\
\hline
\end{tabular}

Pada Tabel 3 memperlihatkan perilaku buang air besar pada rumah tangga, perilaku buang air besar sembarangan dapat meningkatkan kejadian diare. Demikian juga akses air minum yang layak dan ketersediaan sanitasi, terlihat mempunyai proporsi kejadian diare yang lebih kecil. Kemudahan akses pada sarana sanitasi dan air minum ini penting untuk menjaga kesehatan masyarakat.

Tabel 3. Proporsi rumah tangga untuk Perilaku BAB, Akses ke Sarana Air Minum dan Sanitasi

\begin{tabular}{|c|c|c|c|}
\hline \multirow{2}{*}{ Variabel } & \multicolumn{2}{|c|}{ Prevalensi diare $(\%)$} & \multirow{2}{*}{$\mathrm{N}=278.132$} \\
\hline & $\mathrm{Ya}$ & Tidak & \\
\hline \multicolumn{4}{|l|}{ Perilaku BAB } \\
\hline BAB sembarangan & 9,2 & 90,8 & 22.347 \\
\hline BAB di jamban & 6,7 & 93,3 & 255.785 \\
\hline \multicolumn{4}{|c|}{ Akses sarana air minum } \\
\hline Air permukaan & 7,0 & 93,0 & 686 \\
\hline Tidak layak & 7,8 & 92,2 & 14.826 \\
\hline Terbatas & 7,1 & 92,9 & 16.576 \\
\hline Dasar & 6,9 & 93,1 & 246.044 \\
\hline \multicolumn{4}{|l|}{ Akses sanitasi } \\
\hline Tidak digunakan & 8,0 & 92,0 & 288 \\
\hline Tidak layak & 7,5 & 92,5 & 62.984 \\
\hline Terbatas & 7,6 & 92,4 & 19.960 \\
\hline Dasar & 6,7 & 93,3 & 194.900 \\
\hline
\end{tabular}


Gambar 2. Memperlihatkan umumnya dilakukan oleh sekelompok lokasi/tempat $\mathrm{BAB}$ sembarangan yang pada masyarakat.

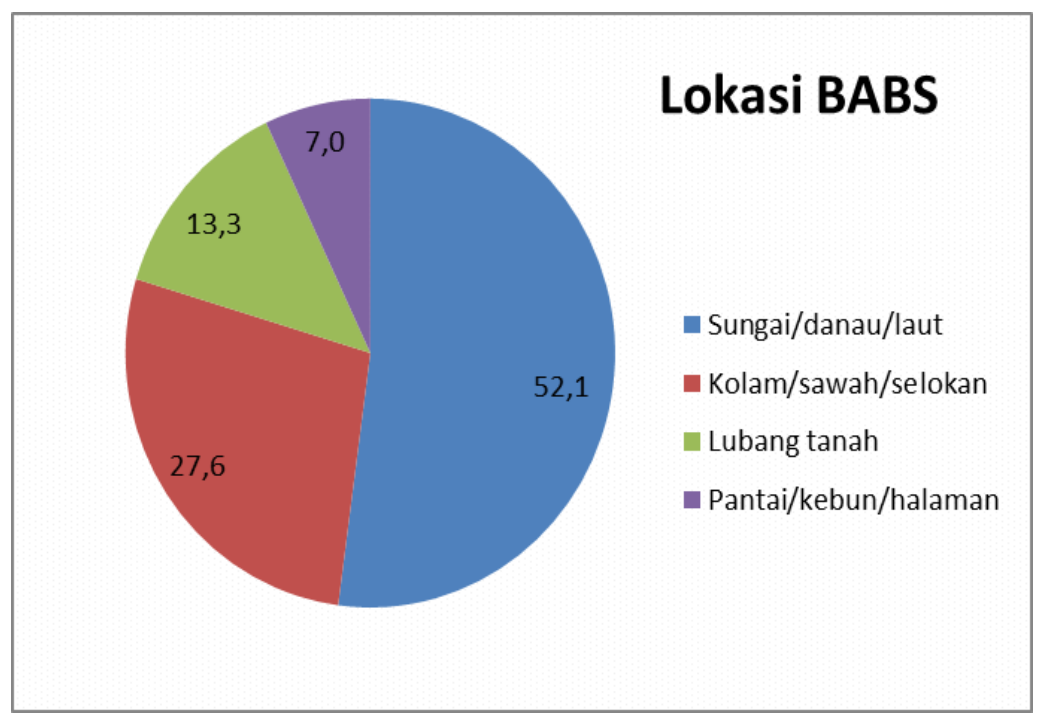

Gambar 2. Tempat buang air besar sembarangan di rumah tangga

Kelompok masyarakat yang melakukan buang air besar sembarangan (BABS), umumnya dilakukan di sungai/danau/laut (52\%). Tempat terbanyak kedua dan ketiga untuk buang air besar sembarangan dilakukan di kolam/sawah/selokan $\quad(27,6 \%)$ kemudian lubang tanah $(13,3 \%)$.

Tabel 4 menunjukkan hasil analisis multivariabel yaitu terjadinya diare dapat berisiko lebih kecil, jika seseorang menggunakan jamban dan air minum yang memenuhi syarat, sehingga selain kriteria tersebut akan mempunyai peluang mengalami kejadian diare. Orang yang berperilaku buang air besar sembarangan walaupun sebenarnya dapat mengakses jamban dapat menyebabkan diare 1,2 kali dibandingkan orang yang $\mathrm{BAB}$ di jamban. Anak usia 0-5 tahun berisiko diare sebesar 1,6 kali dibandingkan usia 6 tahun ke atas.

Tabel 4. Model hubungan perilaku BAB dan akses sanitasi-air minum dengan kejadian diare di Jawa Bali Tahun 2018

\begin{tabular}{|c|c|c|c|c|c|c|}
\hline \multirow{2}{*}{ Variabel } & \multirow{2}{*}{ B } & \multirow{2}{*}{ SE } & \multirow{2}{*}{ Sig } & \multirow{2}{*}{ OR } & \multicolumn{2}{|c|}{ CI 95\% } \\
\hline & & & & & lower & upper \\
\hline \multicolumn{7}{|l|}{ Akses sanitasi dan air minum RT } \\
\hline Sanitasi dan air minum dasar & 1 & & & & & \\
\hline Sanitasi dan air minum terbatas & 0,108 & 0,037 & 0,003 & 1,092 & 1,028 & 1,160 \\
\hline $\begin{array}{l}\text { Sanitasi dan air minum tidak layak dan tidak } \\
\text { tersedia }\end{array}$ & 0,088 & 0,031 & 0,004 & 1,114 & 1,036 & 1,197 \\
\hline \multicolumn{7}{|l|}{ Kebiasaan buang air besar } \\
\hline BAB di jamban & 1 & & & & & \\
\hline BAB sembarangan & 0,184 & 0,038 & 0,000 & 1,202 & 1,116 & 1,294 \\
\hline \multicolumn{7}{|l|}{ Umur } \\
\hline 6 tahun keatas & 1 & & & & & \\
\hline $0-5$ tahun & 0,443 & 0,033 & 0,000 & 1,557 & 1,459 & 1,662 \\
\hline \multicolumn{7}{|l|}{ Pendidikan } \\
\hline SMA-PT & 1 & & & & & \\
\hline SD-SMP & 0,199 & 0,049 & 0,000 & 1,220 & 1,108 & 1,344 \\
\hline Tidak sekolah & 0,287 & 0,049 & 0,000 & 1,333 & 1,210 & 1,468 \\
\hline
\end{tabular}


Pendidikan rendah untuk kelompok umur 6 tahun keatas dan belum sekolah untuk kelompok umur 5 tahun ke bawah mempunyai risiko lebih tinggi untuk mengalami diare (1,3 kali). Pendidikan dan perilaku pada anak umur 5 tahun ke bawah belum merupakan faktor dari anak tersebut, risiko tersebut cenderung ditentukan oleh faktor ibu atau pengasuhnya.

\section{PEMBAHASAN}

Secara umum, hasil penelitian ini menunjukkan bahwa penyakit diare masih menjadi masalah di Indonesia. Hal ini dapat dilihat dari masih tingginya kejadian diare di Jawa dan Bali yaitu sekitar 7 persen dengan persentase terbesar pada anak usia dibawah lima tahun $(10,6 \%)$. Kelompok umur ini merupakan usia yang rentan dan berisiko, bahkan Riskesdas 2007 menyebutkan bahwa diare merupakan penyebab utama kematian pada balita (Kementerian Kesehatan Republik Indonesia, 2008). Beberapa faktor yang dianggap menjadi penyebab tingginya penyakit diare di Jawa dan Bali adalah perilaku tidak higienis yaitu kebiasaan buang air besar sembarangan,akses sanitasi dan air minum yang tidak layak/tidak tersedia. Faktor lainnya adalah usia, yaitu usia dibawah lima tahun dan tingkat pendidikan yang rendah turut berkontribusi pada tingginya penyakit diare.

Salah satu program pemerintah untuk penyediaan air minum dan sanitasi yang layak serta meningkatkan kesadaran dan kemauan masyarakat untuk lebih peduli pada lingkungan dan kesehatan yaitu kegiatan Sanitasi Total Berbasis Masyarakat (STBM). Salah satu pilar STBM adalah tercapainya komunitas (Desa/Kelurahan) Stop Buang Air Besar Sembarangan (SBS) atau disebut juga Open Defecation Free/ODF) (Kementerian Kesehatan Republik Indonesia, 2012). Diharapkan dengan pendekatan STBM akan mendorong masyarakat untuk memiliki rasa malu dan takut terhadap kondisi di lingkungannya (Apriatman, 2011). Permenkes RI No.3/2014 tentang Sanitasi Total Berbasis Masyarakat menjelaskan bahwa STBM adalah pendekatan mengubah perilaku untuk higienis dan saniter melalui pemberdayaan masyarakat dengan cara pemicuan (Kementerian Kesehatan, 2014).

Berdasarkan hasil analisis, bahwa kebiasaan buang air besar sembarangan mempunyai hubungan dengan penyakit diare. Perilaku BABS dapat mencemari lingkungan, baik tanah, air dan udara. Tinja atau kotoran manusia mengandung berbagai kuman patogen atau penyebab penyakit, salah satunya adalah E.coli. Apabila air yang digunakan untuk keperluan sehari-hari telah tercemar tinja, maka akan menimbulkan penyakit. Untuk mencegah terjadinya pencemaran sumber air minum dari tinja, maka buang air besar di jamban merupakan alternatif utama yang harus dilakukan. Hasil penelitian di beberapa negara juga telah membuktikan bahwa penggunaan jamban mempunyai dampak yang besar dalam penurunan risiko penyakit diare (Kemenkes RI, 2011). Penelitian tentang kejadian diare pada anak balita di wilayah OD dan ODF di Ethiopia dan Kenya menyebutkan bahwa prevalensi diare di wilayah OD lebih tinggi dibandingkan wilayah ODF (Njuguna, 2016; Ayalew et al., 2018). Ini membuktikan bahwa kebiasaan buang air besar di jamban dapat menurunkan risiko penyebaran penyakit diare di masyarakat.

Kegiatan STBM di Jawa dan Bali, diantaranya di kabupaten Jombang, Wonosobo, Tegal dan Gianyar telah menunjukkan keberhasilannya, hal ini terlihat dalam turunnya kasus diare di wilayah tersebut (Dwipayanti and Sutiarini, 2013; Falasifa, 2015; Mukti, Raharjo and Dewanti, 2016; Elsa Putri Lahudin, 2017). Keberhasilan program STBM ini diharapkan agar lebih banyak masyarakat yang memiliki kesadaran untuk berperilaku buang air besar di jamban serta dapat mendorong masyarakat untuk membangun sarana sanitasi secara mandiri sesuai kemampuan.

Hasil penelitian ini menunjukkan bahwa, ketersediaan sanitasi dan air minum juga mempengaruhi kejadian diare di masyarakat. Hasil studi WHO menyatakan bahwa risiko penyakit lingkungan dapat diturunkan hingga 94\% dengan melakukan modifikasi lingkungan, diantaranya adalah penyediaan air minum dan pemanfaatan jamban (Kementerian Kesehatan Republik Indonesia, 2012). Dampak dari akses yang 
buruk pada sarana air minum dan sanitasi dapat meningkatkan kejadian diare di masyarakat (Wulandari, 2009; Hutton and Chase, 2017). Sumber air yang tidak terlindung serta jarak dengan sumber pembuangan tinja kurang dari 10-meter serta jamban yang tidak layak karena tidak dilengkapi dengan tangki septik dapat meningkatkan risiko terjadinya diare. Jamban juga harus dalam keadaan bersih, sehat dan tidak berbau, agar tidak mengundang lalat atau serangga yang dapat menjadi penular penyakit diare (UNICEF/WHO, 2009; Putranti and Sulistyorini, 2013; Wandansari, 2013; WHO, 2018).

Masalah sanitasi dan air minum rumah tangga merupakan determinan utama untuk meningkatkan derajat kesehatan masyarakat di dunia. Walaupun tidak secara eksplisit termasuk dalam isu kesehatan, namun ketersediaan sanitasi yang layak dan akses air minum tercantum dalam tujuan ke6, terutama target 6.2 dan 6.3 tentang ketersediaan sanitasi dan air minum yang layak (WHO, 2018). Hal ini harus menjadi perhatian, karena akses air minum dan sanitasi merupakan kebutuhan dasar manusia dan negara wajib memenuhi kebutuhan dasar tersebut.

Hasil penelitian ini juga membuktikan, bahwa anak usia 0 - 5 tahun lebih mudah terserang diare dibandingkan usia di atasnya. Pada usia muda, berat tubuh anak lebih banyak mengandung air yang digunakan dalam metabolime tubuh. Selain itu, sistem imun anak juga belum sempurna sehingga lebih rentan terjangkit penyakit (UNICEF/WHO, 2009). Pada balita (bawah lima tahun), faktor diare juga sangat dipengaruhi oleh perilaku ibu, karena balita belum bisa menjaga dirinya sendiri dan sangat tergantung dengan lingkungannya. Jadi, pengetahuan ibu dan keluarga sangat diperlukan untuk menghindari kejadian diare pada balita (Anggraini, Aviyanti and Saputri, 2014).

Faktor lain yang yang merupakan elemen penting dalam menurunkan prevalensi diare di masyarakat adalah jenjang pendidikan. Masyarakat dengan pendidikan yang tinggi, akan mudah menerima informasi dan pengetahuan baru sehingga bisa menurunkan kemungkinan terkena diare
(Semba et al., 2011; Woldu, Bitew and Gizaw, 2016; Hutton and Chase, 2017; Oliveira et al., 2017; Sintayehu et al., 2019). Masyarakat dengan pendidikan tinggi, cenderung lebih menanamkan dan melaksanakan perilaku hidup sehat Sedangkan masyarakat dengan pendidikan rendah, perilaku hidup sehat yang dilakukan hanya berdasarkan pengalaman tanpa mempertimbangkan dan menganalisis akibat yang terjadi. Kadangkala, mereka sulit untuk diberi pengertian tentang pentingnya kebersihan perorangan dan sanitasi lingkungan, yang menyebabkan mereka tidak peduli terhadap upaya pencegahan penyakit diare.

Perubahan perilaku masyarakat untuk berperilaku higienis yaitu buang air besar di jamban, harus menjadi prioritas utama pemerintah dalam rangka menurunkan penyakit diare. Akses ke sanitasi dasar berupa jamban sehat juga menjadi faktor yang penting, karena dengan adanya jamban sehat akan menjadi motivasi masyarakat untuk menciptakan hidup sehat dan lingkungan bersih. Kebutuhan air minum rumah tangga juga menjadi penting, karena air merupakan kebutuhan utama dalam kehidupan sehari-hari. Oleh karena itu, perilaku yang sehat (tidak BABS), akses ke sanitasi dan air minum dasar merupakan parameter penentu derajat kesehatan manusia.

Penelitian ini memiliki keterbatasan yaitu tidak melakukan analisis pada perilaku cuci tangan, baik ketersediaan tempat cuci tangan dan kebiasaan dalam melakukan cuci tangan. Variabel tersebut tidak kami analisis karena penelitian ini difokuskan pada perilaku buang air besar dan ketersediaan sanitasi dan air minum di rumah tangga.

\section{KESIMPULAN DAN SARAN}

\section{Kesimpulan}

Berdasarkan hasil analisis dapat disimpulkan bahwa faktor yang penting dalam mencegah diare adalah perilaku. Perilaku buang air besar di jamban sangat berpotensi dalam menekan penyebaran penyakit diare, sehingga tidak cukup hanya menyediakan sarana tempat $\mathrm{BAB}$ dan sumber air yang layak. 


\section{Saran}

Hasil analisis menunjukkan proporsi diare tinggi di kelompok pendidikan rendah dan faktor perilaku yang lebih berperan, maka disarankan semua lembaga yang bergerak di bidang kesehatan, pendidikan, budaya, dan ekonomi dapat membuat program untuk memberikan perubahan perilaku masyarakat melalui media formal (sekolah) dan informal (PKK, siaran TV, dll). Menggunakan budaya setempat dan disampaikan berulang-ulang sehingga tanpa disadari tertanam dalam pemikiran masyarakat

\section{UCAPAN TERIMAKASIH}

Puji syukur kepada Allah SWT sehingga analisis ini terselesaikan. Penulis mengucapkan banyak terima kasih kepada Badan Litbangkes yang telah memberikan kesempatan untuk berpartisipasi dalam Riskesdas, menganalisis lebih lanjut dan memberi kesempatan untuk mempublikasikannya. Ucapan terima kasih juga penulis sampaikan kepada para pihak yang telah berpartisipasi dalam penulisan artikel ini.

\section{KONTRIBUSI PENULIS}

Pernyataan tentang kontribusi penulis: ID dan DH mempunyai peran yang sama dalam penulisan artikel ini. ID menyusun manuskript dan DH melakukan data analisis dan pembahasan hasil analisis. Semua penulis menyetujui hasil akhir dari naskah ini.

\section{DAFTAR PUSTAKA}

Anggraini, M. T., Aviyanti, D. and Saputri, D. M. (2014) 'PHBS yang Buruk Meningkatkan Kejadian Diare', Jurnal Kedokteran Muhammadiyah, 3(1), pp. 1-6.

Apriatman, N. (2011) Stop Buang Air Besar Sembarangan. Jakarta: WASPOLA Facility.

Ayalew, A. M. et al. (2018) 'Assessment of diarrhea and its associated factors in under-five children among open defecation and open defecation-free rural settings of Dangla District, Northwest Ethiopia', Journal of Environmental and Public Health, 2018. doi 10.1155/2018/4271915
Badan Pusat Statistik et al. (2015) Mewujudkan Aksesibilitas Air Minum dan Sanitasi yang Aman dan Berkelanjutan Bagi Semua: Hasil Survey Kualitas Air di Daerah Istimewa Yogyakarta Tahun 2015. Jakarta: Badan Pusat Stistik.

Dinas Kesehatan Provinsi Bali (2018) Profil Kesehatan Provinsi Bali 2017. Bali.

Dinas Kesehatan Provinsi Jawa Barat (2017) Profil Kesehatan Dinas Kesehatan Provinsi Jawa Barat 2017, Diskes Jabarprov. Bandung. Available at: http://diskes.jabarprov.go.id/dmdocuments/0 1b3018430a412a520e2b4a4b9d9864f.pdf.

Dinas Kesehatan Provinsi Jawa Tengah (2018) Profil Kesehatan Provinsi Jawa Tengah 2017, Dinkes Jateng. Semarang. doi: 10.5606/totbid.dergisi.2012.10.

Dinkes Provinsi DKI Jakarta (2016) Profil Kesehatan DKI Jakarta, Dinkes Prov DKI Jakarta. Jakarta.

Dwipayanti, N. and Sutiarini, N. (2013) 'Implementasi Sanitasi Total Berbasis Masyarakat (STBM) Bersama Program KKN di Desa Taro Gianyar', Udayana Mengabdi, 12(1), pp. 2731.

Elsa Putri Lahudin (2017) Sanitasi Total Berbasis Masyarakat (STBM) Dengan Kejadian Diare. STIK Insan Cendekia Medika. doi: 10.1017/CBO9781107415324.004

Falasifa, M. (2015) Hubungan Antara Sanitasi Total Dengan Kejadian Diare pada Balita di WilayahnKerja Puskesmas Kepil 2 Kecamatan Kepil Kabupaten Wonosobo Tahun 2015. Universitas Negeri Semarang.

Hutton, G. and Chase, C. (2017) 'Water, Sanitation, and Hygiene', in Injury Prevention and Environmental Health. 3rd Editio. Washimgton DC: World Bank, pp. 171-198. doi: 10.1596/978-1-4648-0522-6_ch6.

Kemenkes RI (2011) 'Situasi diare di Indonesia', Jurnal Buletin Jendela Data \& Informasi Kesehatan, 2, pp. 1-44.

Kemenkes RI (2018) 'Laporan Hasil Riset Kesehatan Dasar (Riskesdas) Indonesia tahun 2018', Riset Kesehatan Dasar 2018, pp. 182-183.

Kemenkes RI (2019) Profil Kesehatan Indonesia 2018. Jakarta: Kementerian Kesehatan. Available at:

http://www.depkes.go.id/resources/download /pusdatin/profil-kesehatan-indonesia/Datadan-Informasi_Profil-Kesehatan-Indonesia2018.pdf.

Kementerian Kesehatan (2014) Peraturan Menteri Kesehatan Republik Indonesia Nomor 3 Tahun 2014. Indonesia: Kementerian Kesehatan.

Kementerian Kesehatan Republik Indonesia (2008) Riset Kesehatan Dasar 2007, Badan Penelitian dan Pengembangan Kesehatan. Jakarta. doi: 1 Desember 2013.

Kementerian Kesehatan Republik Indonesia (2012) Pedoman Pelaksanaan Teknis STBM Tahun 2012, Kesehatan. Available at: http://stbm.kemkes.go.id/public/docs/referenc e/5b99c4c2576e12f4c9a2019139312658b2f3 704c9abc5.pdf. 
Kesehatan Kemenkes RI (2020) Data dan Informasi Profil Kesehatan Indonesia 2019, Kementrian Kesehatan RI. Jakarta: Pusat Data dan Informasi. Kemenkes. doi: 10.1017/CBO9781107415324.004.

Mukti, D., Raharjo, M. and Dewanti, N. (2016) 'Hubungan Antara Penerapan Program Sanitasi Total Berbasis Masyarakat (STBM) Dengan Kejadian Diare Di Wilayah Kerja Puskesmas Jatibogor Kabupaten Tegal', Jurnal Kesehatan Masyarakat Universitas Diponegoro, 4(3), pp. 767-775.

Njuguna, J. (2016) 'Effect of eliminating open defecation on diarrhoeal morbidity: An ecological study of Nyando and Nambale sub-counties, Kenya', BMC Public Health. BMC Public Health, 16(1), pp. 2-7. doi: 10.1186/s12889-016-3421-2.

Oliveira, R. K. L. de et al. (2017) 'Influence of socioeconomic conditions and maternal knowledge in self-effectiveness for prevention of childhood diarrhea', Escola Anna Nery, 21(4), pp. 1-9. doi: 10.1590/2177-9465-ean2016-0361.

Putranti, D. and Sulistyorini, L. (2013) 'Hubungan antara Kepemilikan Jamban dengan Kejadian Diare di Desa Karangagung Kecamatan Palang Kabupaten Tuban', Jurnal Kesehatan Lingkungan, 7(1), pp. 54-63. Available at: http://journal.unair.ac.id/downloadfullpapers-keslingb03cb54364full.pdf.

Semba, R. D. et al. (2011) 'Relationship of the presence of a household improved latrine with diarrhea and under-five child mortality in Indonesia', American Journal of Tropical Medicine and Hygiene, 84(3), pp. 443-450. doi: 10.4269/ajtmh.2011.10-0244.

Sintayehu, M. et al. (2019) 'Prevalence of Diarrhea and Its Associated Factors among Under-Five Children in Open Defecation Free and NonOpen Defecation Free Households in Goba District Southeast Ethiopia: A Comparative
Cross-Sectional Study', Clinics Mother Child Health, 16(324), pp. 1-9.

Soekidjo, N. (2003) 'Ilmu Kesehatan Masyarakat'.

Statistik, B. P. et al. (2016) Mewujudkan Aksesibilitas Air Minum dan Sanitasi yang Aman dan Berkelanjutan Bagi Semua.

UNICEF/WHO (2009) Diarrhoea: Why children are still dying and what can be done, Unicef WHO. New York, USA: UNICEF/WHO. doi: 10.1016/S0140-6736(10)60678-2.

Wandansari, A. P. (2013) 'Kualitas Sumber Air Minum Dan Pemanfaatan Jamban Keluarga Dengan Kejadian Diare', Jurnal Kesehatan Masyarakat, 9(1), pp. 24-29. doi: 10.15294/kemas.v9i1.2826

WHO (2007) Combating waterborne disease at the household level. Geneva, Switzerland.

WHO (2018) Guidelines on sanitation and health., World Health Organization. Available at: http://www.who.int/water_sanitation_health/ publications/guidelines-on-sanitation-andhealth/en/.

Woldu, W., Bitew, B. D. and Gizaw, Z. (2016) 'Socioeconomic factors associated with diarrheal diseases among under-five children of the nomadic population in northeast Ethiopia', Tropical Medicine and Health, 44(1), pp. 1-14. doi: 10.1186/s41182-0160040-7.

World Gastroenterology Organisation (2012) Acute diarrhea in adults and children: A global perspective, World Gastroenterology Organisation Global Guidelines. Milwaukee, Wisconsin: WGO. Available at: https://journals.lww.com/jcge/fulltext/2013/0 1000/Acute_Diarrhea_in_Adults_and_Childr en_A_Global.7.aspx.

Wulandari, A. P. (2009) Hubungan antara faktor lingkungan dan faktor sosiodemografi dengan kejadian diare pada balita di desa Blimbing kecamatan Sambirejo kabupaten Sragen tahun 2009. 